\title{
IMPACT OF SLUDGE AND WASTEWATER ON LACTUCA SATIVA L GROWTH AND ON SOIL POLLUTION
}

\author{
NTZALA G. ${ }^{1}$ \\ KALAVROUZIOTIS I.K. ${ }^{2, *}$ \\ KOUKOULAKIS P.H. ${ }^{3}$ \\ PAPADOPOULOS A.H. ${ }^{3}$
}

\author{
${ }^{1}$ Department of Environmental and Natural Resources Management \\ University of Patras, G. Seferi 1, Agrinio, Greece \\ ${ }^{2}$ School of Science and Technology \\ Hellenic Open University, Aristotelous 18, 26 335, Patras, Greece \\ ${ }^{3}$ Soil Science Institute, of Thessaloniki \\ GR-570 01, Thermi, Thessaloniki|Greece
}

Received: $14 / 02 / 2014$

Accepted: $27 / 12 / 2014$

Available online: 25/02/2015 *to whom all correspondence should be addressed: e-mail: ikalabro@eap.gr

\section{ABSTRACT}

Two greenhouse pot experiments were conducted in Agrinion, Greece. The impact of treated municipal wastewater (TMWW) and sludge (i) on the growth of Lactuca sativa L. var Longifolia (lettuce) and (ii) on the extent of soil pollution with heavy metals was studied. Soil pollution was assessed by calculating the Pollution Load Index (PLI). Both of these experiments were conducted, using a randomized block design in four replications and seven treatments, respectively, as follows: (a) Experiment A: study of the effect of treated municipal wastewater (TMWW): [Control, 20\%, 40\%, 60\%, $80 \%, 100 \%,(100 \%+30 \mathrm{t} / \mathrm{ha}$ Sludge)] and (b) Experiment B: Study of the effect of sludge (t/ha): 0, 6, 12, $18,24,30,(30+100 \%$ TMWW). The sludge affected significantly plant height and fresh and dry matter yield, as well as the dry matter $\mathrm{N}$ content of plants, while the TMWW affected significantly the dry matter yield and non-significantly the plant height. The pollution load index (PLI) was non-significant for both treatments (sludge and TMWW). According to PLI calibration scale, the soil was found to be slightly polluted with heavy metals under both treatments.

Keywords: Treated municipal wastewater, heavy metals, sludge, Pollution Load Index (PLI), Lactuca sativa L

\section{Introduction}

Sludge, a product of wastewater treatment, contains organic matter, essential plant nutrients ( $N, P, K$, $\mathrm{Ca}, \mathrm{Mg}, \mathrm{Fe}, \mathrm{Zn}, \mathrm{Mn}, \mathrm{Cu}$, and $\mathrm{B}$ ) and variable amounts of various heavy metals $(\mathrm{Cd}, \mathrm{Cr}, \mathrm{Pb}, \mathrm{Hg}, \mathrm{Ni})$ rendering its application to soil, problematic. Therefore, it requires special management. The main concern about the sludge is related to phytotoxicity, due to the accumulation of heavy metals in the soil (Stabnikova et al., 2005), a fact that calls for special management of this soil input. Generally, the heavy metal accumulation in soil restricts its proper and effective functioning, because it may cause toxicity to plants, and affects unfavorably the food chain and human health.

The heavy metals could be very toxic at high concentrations, and they may cause serious problems to the environment, plants, and human health (WHO, 1992). For example, long term exposure to $\mathrm{Pb}$ may lead to the deterioration of memory, causing reduced ability of understanding, behavioral disturbances, and learning difficulties (Jarup, 2003). Chronic poisoning after several years of exposure 
to $\mathrm{Cd}$ may cause cadmium-induced nephropathy which is characterized by increased proteinuria, in particular 2-microglobulin (Friberg, 1948; Tsuchiya, 1967).

Long term use of sludge, may increase the soil levels of $\mathrm{Zn}, \mathrm{Cu}, \mathrm{Ni}, \mathrm{Cr}, \mathrm{Cd}, \mathrm{Pb}$, and $\mathrm{Hg}$, but only $\mathrm{Zn}, \mathrm{Cu}$, $\mathrm{Ni}$ and $\mathrm{Cd}$ may increase in the dry matter of cereal grains, while $\mathrm{Zn}, \mathrm{Cu}, \mathrm{Cr}$ and $\mathrm{Pb}$ are increased in grains of wheat (Purves, 1977). Also application of sludge to grain sorghum increased the heavy metal content, but due to the short term effect, their levels were below the accepted critical concentrations (Akdeniz et al., 2006). However, long term application must be managed accordingly to avoid toxic effects. Similarly, long term irrigation with TMWW may increase the heavy metal contents of soil, and therefore the assessment of soil metal accumulation is of vital importance.

Wastewater, and sludge have long been used as fertilizers and as irrigation water, especially as supplementary sources of $\mathrm{N}$ and other macro and micronutrients, also as amendment for the improvement of soil physical properties (Pereira et al., 2011; Liu et al., 2005; NRC, 1996; Metcalf and Eddy, 1991).

Large quantities of domestic sludge are produced every year. For example, the estimated annual quantity of sludge produced by 13 member countries in EU during 1999 was $7,136 \times 10^{3} \mathrm{t}$ of dry matter. In the European Union (EU), almost all countries, have soils which are polluted with heavy metals (Ferguson, 1999), and protection of soils from heavy metal pollution has been one of the first priorities (EC, 2002). Also, in China nearly $1 / 5$ of the total area $\left(2.0 \times 10^{7} \mathrm{hm}^{2}\right)$ is contaminated with heavy metals (Zang et al., 2012). Similarly, in India, large areas in the Patancheru region have been affected by the accumulation of heavy metals (Govil et al., 2001).

It has been reported (Adriano 2001) that heavy metals rank very high among the chief contaminants of vegetables, as they appear to be more effectively accumulated in the edible plant parts. However, the sludge-borne metals have been reported as having lower phytotoxicity than the added metals, that is why phytotoxicity symptoms are very rarely observed even after application of large amounts of sludge (Adriano, 2001).

Reuse of treated municipal wastewater (TMWW) and sludge enriches soil with heavy metals, which affect crop yield and soil fertility (FAO, 2003). Thus, when high doses of sludge and TMWW are used, the accumulation of heavy metals, may exceed the critical concentration limits, and consequently may create toxic effects on plants.

In spite of the problems associated with the use of sludge as an alternative fertilizer or soil amendment material in agriculture, sludge is gaining popularity in many countries such as in the region of Near East (Egypt, Syria, Saudi Arabia, etc.) (FAO, 2003), China (Liu et al., 2005), Iran (Kalavrouziotis et al., 2013), and Brazil (Pereira et al., 2011). It is used in agriculture such as for the production of field crops, (maize, sorghum, forage crops), and vegetables (Antonius et al., 2010).

The purpose of the present study is to evaluate the effects of application of sludge and of the TMWW on lettuce (Lactuca sativa L. var, longifolia) growth and to assess the extent of soil pollution with heavy metals.

\section{Materials and methods}

Two greenhouse pot experiments were conducted, for the study of the effect of sludge and TMWW on lettuce plant growth and mineral content and on soil pollution, as follows:

Experiment A: Seven sludge treatment levels were applied, the $7^{\text {th }}$ one being a combination of the highest sludge level plus 100\% TMWW.

Experiment B: Seven TMWW treatment levels, were studied, the $1^{\text {st }}$ one being the control (natural water) and the $7^{\text {th }}$ one being a combination of $100 \%$ TMWW and the highest level of sludge (Table 1 ). 
Table 1. Experimental treatment levels of sludge and TMWW

\begin{tabular}{|c|c|c|c|c|c|c|}
\hline \multirow{2}{*}{$\begin{array}{c}\text { Serial } \\
\text { number }\end{array}$} & \multirow{2}{*}{ Treatments } & \multirow{2}{*}{ Treatment level } & \multicolumn{2}{|c|}{ Dried sludge } & \multicolumn{2}{|c|}{ fresh sludge } \\
\hline & & & $\mathrm{g} / \mathrm{pot}$ & $\mathrm{kg} / \mathrm{ha}$ & $\mathrm{g} / \mathrm{pot}$ & $\mathrm{kg} / \mathrm{ha}$ \\
\hline \multicolumn{7}{|c|}{ I-Experimental study of the effect of TMWW on the soil } \\
\hline 1 & Control (C) & Natural fresh well water & - & - & - & - \\
\hline 2 & $\mathrm{TMWW}_{1}$ & 20\%TMWW+80\%Control & - & - & - & - \\
\hline 3 & $\mathrm{TMWW}_{2}$ & 40\%TMWW+60\%Control & - & - & - & - \\
\hline 4 & $\mathrm{TMWW}_{3}$ & $60 \%$ TMWW+40\%Control & - & - & - & - \\
\hline 5 & $\mathrm{TMWW}_{4}$ & $80 \%$ TMWW+20\%Control & - & - & - & - \\
\hline 6 & TMWW $_{5}$ & 100\%TMWW+0\%Control & - & - & - & - \\
\hline \multicolumn{7}{|c|}{ II- Experimental study of the effect of sludge on the soil } \\
\hline 7 & $\mathrm{~S}_{1}$ & - & 22.6 & 600 & 41.8 & 1110 \\
\hline 8 & $\mathrm{~S}_{2}$ & - & 45.2 & 1200 & 83.6 & 2220 \\
\hline 9 & $\mathrm{~S}_{3}$ & - & 67.7 & 1800 & 125 & 3330 \\
\hline 10 & $\mathrm{~S}_{4}$ & - & 90.3 & 2400 & 167 & 4440 \\
\hline 11 & $\mathrm{~S}_{5}$ & - & 113 & 3000 & 199 & 5550 \\
\hline 12 & $\mathrm{TMWW}_{5}+\mathrm{S}_{5}$ & - & $113+$ TMWW $_{5}$ & $3000+$ TMWW $_{5}$ & 199 & $5550+\mathrm{TMWW}_{5}$ \\
\hline
\end{tabular}

Both the sludge and the TMWW were derived from the wastewater processing plant (WPP) of Mesolongion, W.Greece. The sludge used was subjected to partial dehydration, aerobic biological stabilization, denitrification and dephosphorization.

The experiments were conducted in a non-heated greenhouse, and in pots with a total volume of $6 \mathrm{~L}$, containing $10 \mathrm{~kg}$ of air dried soil, of known moisture content $\left(12.5 \%\right.$, determined at $\left.100{ }^{\circ} \mathrm{C}\right)$. Both experiments were conducted, using a completely randomized block design, including seven TMWW and sludge treatments, respectively, as shown in Table 1, both in four replications, with a total number of pots per experiment equal to 28 .

In each pot, two young lettuce plants were transplanted, i.e. in total 112 plants. The vegetable lettuce or Lactuca sativa L. var longifolia was used as an experimental test plant. This plant was chosen because it is one of the main leafy vegetables consumed in Greece, and it grows very easily and produces biomass in a relatively short time under relatively cool conditions.

The sludge treatments were mixed with the soil according to Table 1 , before being transferred into the pots. The soil was mixed thoroughly by means of a plastic rod, and it was transferred into the pot. Then, transplanting took place and the plants were irrigated with TMWW or fresh water, according to the experimental design.

The sludge used was watery containing $15 \%$ dry matter. The quantities of sludge shown in Table 1 were calculated on the basis of the above dry matter percent content. The transplanting was done on $15 / 11 / 2012$ and the harvest on 20/03/2013. The growth period of lettuce lasted eighteen (18) weeks. Composite soil samples, i.e. each one being composed of a mixture of 3-4 subsamples were taken as follows:

1-Selection of the experimental soil: One composite sample was taken from three respective selected areas, based on the determination of the physical and chemical characteristics $(\mathrm{pH}, \mathrm{EC}$, mechanical analysis, and $\mathrm{CaCO}_{3}$ ), which would be compatible with soil needs of the lettuce plants. A quantity of about $700 \mathrm{~kg}$ of the chosen soil, which satisfied the requirements of the experiment, was then taken to be used as the experimental soil for filling the pots.

2-From this experimental soil mass, a composite sample of about $1 \mathrm{~kg}$ was taken for the detailed determination of physical, chemical characteristics, and macro, micronutrients which were as follows: Mechanical analysis light sandy loam (SL), slightly acid pH 6.52, low salinity $\left(0.829 \mathrm{mS} \mathrm{cm}^{-1}\right)$, moderate organic matter content $(1.47 \%)$, rich in Olsen $\mathrm{P}\left(112.1 \mathrm{mg} \mathrm{kg}^{-1}\right)$, and adequately supplied with $\mathrm{Zn}$ (1.06 $\left.\mathrm{mg} \mathrm{kg}^{-1}\right), \mathrm{Mg}\left(330 \mathrm{mg} \mathrm{kg}^{-1}\right), \mathrm{Mn}\left(28.5 \mathrm{mg} \mathrm{kg}^{-1}\right)$ and $\mathrm{Cu}\left(2.53 \mathrm{mg} \mathrm{kg}^{-1}\right)$. 
3-Pot soil sampling: Composite soil samples of $0.3 \mathrm{~kg}$ were taken from each pot during the middle plant growth period, and also at the completion of the experiment.

The first sampling of soil from the pots was conducted about three (3) months or twelve (12) weeks $(17 / 02 / 2011)$ from transplanting, and the second eighteen (18) weeks after transplanting $(20 / 03 / 2011)$, i.e. at the completion of the experiment.

Along with the soil sampling, whole plant samples were also taken from each treatment (pot) during both the mid-growth period and at harvesting. One of the two plants was separated into roots and above-ground section (head) and the other one was kept intact (whole plant).

Roots, heads, and whole plants of lettuce of both samplings, along with the soil samples, were chemically analyzed for macro, micronutrients and heavy metals.

\subsection{Soil and Sludge Analysis}

Chemical determinations were made on the soil samples as follows: soil mechanical analysis by the classical Bouyoucos method, $\mathrm{pH}$ measured on water extract of saturated paste using a standard $\mathrm{pH}$ meter, $\mathrm{CaCO}_{3}$ by the method of Bernard, salinity of the saturated extract by a conductivity meter, available soil P by Olsen et al. (1954), ex-changeable K according to Lanyon and Heald, (1982), Ca \& Mg according to Richards, (1954), micronutrients Fe, Zn, Mn \& Cu were extracted with DTPA (Lindsay and Norvell, 1978), and similarly heavy metals $\mathrm{Cd}, \mathrm{Ni}, \mathrm{Co}, \mathrm{Pb}, \mathrm{Cr}$ were extracted with DTPA (Ure, 1995). Micronutrients and heavy metals were measured by inductively coupled plasma emission spectroscopy (ICP - ES) (Soltanpour et al., 1998). The mean results of soil analysis are given in Table 2 .

Table 2. Soil physical chemical characteristics, and macro, micronutrient and heavy metal content under the effect of sludge and TMWW, respectively

\begin{tabular}{|c|c|c|c|c|}
\hline \multirow{2}{*}{$\begin{array}{l}\text { Soil Characteristic } \\
\qquad(n=56)\end{array}$} & \multicolumn{2}{|c|}{ SLUDGE } & \multicolumn{2}{|c|}{ TMWW $^{\mathrm{a}}$} \\
\hline & $\begin{array}{c}\text { Mean } \\
\text { content }\end{array}$ & $\begin{array}{l}\text { Standard } \\
\text { deviation }\end{array}$ & $\begin{array}{c}\text { Mean } \\
\text { content }\end{array}$ & Standard deviation \\
\hline $\mathrm{pH}$ & 5.76 & 0.234 & 5.68 & 0.281 \\
\hline $\mathrm{EC}\left(\mathrm{mS} \mathrm{cm}^{-1}\right)$ & 0.52 & 0.626 & 1.22 & 0.744 \\
\hline OM (\%) & 1.56 & 0.222 & 1.52 & 0.235 \\
\hline Total N (\%) ${ }^{\mathrm{b}}$ & 0.12 & 0.016 & 0.116 & 0.019 \\
\hline $\mathrm{P}\left(\mathrm{mg} \mathrm{kg}^{-1}\right)$ & 99.6 & 15.2 & 99.7 & 16.1 \\
\hline $\mathrm{K}\left(\mathrm{mg} \mathrm{kg}^{-1}\right)$ & 108 & 26.4 & 118 & 28.5 \\
\hline $\mathrm{Ca}\left(\mathrm{mg} \mathrm{kg}^{-1}\right)$ & 197 & 19.9 & 199 & 20.4 \\
\hline $\mathrm{Mg}\left(\mathrm{mg} \mathrm{kg}^{-1}\right)$ & 30.3 & 13.5 & 33.4 & 15.0 \\
\hline $\mathrm{Fe}\left(\mathrm{mg} \mathrm{kg}^{-1}\right)$ & 25.1 & 2.73 & 23.5 & 2.73 \\
\hline $\mathrm{Zn}\left(\mathrm{mg} \mathrm{kg}^{-1}\right)$ & 2.30 & 0.931 & 2.11 & 1.38 \\
\hline $\mathrm{Mn}\left(\mathrm{mg} \mathrm{kg}^{-1}\right)$ & 41.4 & 8.54 & 39.9 & 8.31 \\
\hline $\mathrm{Cu}\left(\mathrm{mg} \mathrm{kg}^{-1}\right.$ & 2.32 & 0.480 & 2.27 & 0.504 \\
\hline $\mathrm{Cr}\left(\mathrm{mg} \mathrm{kg}^{-1}\right)$ & 0.042 & 0.012 & 0.038 & 0.015 \\
\hline $\mathrm{Cd}\left(\mathrm{mg} \mathrm{kg}^{-1}\right)$ & 0.061 & 0.017 & 0.058 & 0.015 \\
\hline Co $\left(\mathrm{mg} \mathrm{kg}^{-1}\right)$ & 0.073 & 0.052 & 0.072 & 0.051 \\
\hline $\mathrm{Ni}\left(\mathrm{mg} \mathrm{kg}^{-1}\right)$ & 0.355 & 0.082 & 0.339 & 0.081 \\
\hline $\mathrm{Pb}\left(\mathrm{mg} \mathrm{kg}^{-1}\right)$ & 5.52 & 2.81 & 5.40 & 3.13 \\
\hline
\end{tabular}

a Treated municipal wastewater, ${ }^{\mathrm{b}}(\mathrm{n}=28)$

Furthermore, chemical analysis was made of dried sludge for the determination of extractable DTPA content of heavy metals and other nutrients (AOAC, 1996). The attained results are indicated in Table 3.

\subsection{Plant Analysis}

Root samples were washed by standard procedure, i.e. complete removal of soil particles by means of low-pressure tap water, followed by cleaning with dilute solution of $0.001 \% \mathrm{HCl}$ and with $0.1 \%$ 
Alcoonox solution (Kalavrouziotis et al., 2008). Then, they were dried at $70^{\circ} \mathrm{C}$ and were ground. Leaf and head samples were also washed according to the above procedure (Kalavrouziotis et al, 2013).

The plant samples were mineralized by heating $1.0 \mathrm{~g}$ in a muffle furnace at $500^{\circ} \mathrm{C}$ for $10-12 \mathrm{~h}$, and the ash was dissolved in a solution $50: 50 \mathrm{v} / \mathrm{v} \mathrm{H}_{2} \mathrm{O} / \mathrm{HCl}$, which was used for the measurement of micronutrients and heavy metals by ICP-ES (Soltanpour et al., 1998). The results obtained are given in Table 4.

Table 3. Physical and chemical characteristics and DTPA extractable, macro, micronutrient and heavy metal content of sludge.,

\begin{tabular}{ccccccccccccccc}
\hline \multirow{2}{*}{$\mathrm{pH}$} & $\begin{array}{c}\mathrm{EC} \\
(\mathrm{mS} \\
\mathrm{cm}\end{array}$ & $\mathrm{P}$ & $\mathrm{K}$ & $\mathrm{Ca}$ & $\mathrm{Mg}$ & $\mathrm{Fe}$ & $\mathrm{Zn}$ & $\mathrm{Mn}$ & $\mathrm{Cu}$ & $\mathrm{Cr}$ & $\mathrm{Cd}$ & $\mathrm{Co}$ & $\mathrm{Ni}$ & $\mathrm{Pb}$ \\
\hline 6.29 & 13.7 & 777.7 & 3333 & 460 & 309 & 221.5 & 171.8 & 43.6 & 22.70 & 0.32 & 0.36 & 0.61 & 3.7 & 322.3 \\
\hline
\end{tabular}

Table 4. Mean lettuce head, roots and whole plant macro, micronutrient and heavy metal content ( $\mu \mathrm{g} \mathrm{g}^{-1}$ dry matter)

\begin{tabular}{|c|c|c|c|c|c|c|c|c|c|c|c|c|}
\hline \multirow{3}{*}{ 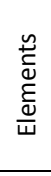 } & \multicolumn{4}{|c|}{ HEADS } & \multicolumn{4}{|c|}{ ROOTS } & \multicolumn{4}{|c|}{ WHOLE PLANT } \\
\hline & \multicolumn{2}{|c|}{ Sludge } & \multicolumn{2}{|c|}{ TMWW } & \multicolumn{2}{|c|}{ Sludge } & \multicolumn{2}{|c|}{ TMWW } & \multicolumn{2}{|c|}{ Sludge } & \multicolumn{2}{|c|}{ TMWW } \\
\hline & $\begin{array}{c}\mu \mathrm{g} \mathrm{g}^{-1} \\
\mathrm{dm}\end{array}$ & $\begin{array}{c}\text { Stand } \\
\text { Dev }\end{array}$ & $\begin{array}{c}\mu \mathrm{g} \mathrm{g}^{-1} \\
\mathrm{dm}\end{array}$ & $\begin{array}{c}\text { Stand } \\
\text { Dev }\end{array}$ & $\begin{array}{c}\mu \mathrm{g} \mathrm{g}^{-1} \\
\mathrm{dm}\end{array}$ & $\begin{array}{c}\text { Stand } \\
\text { Dev }\end{array}$ & $\begin{array}{c}\mu \mathrm{g} \mathrm{g}^{-1} \\
\mathrm{dm}\end{array}$ & $\begin{array}{c}\text { Stand } \\
\text { Dev }\end{array}$ & $\begin{array}{c}\mu \mathrm{g} \mathrm{g}^{-1} \\
\mathrm{dm}\end{array}$ & $\begin{array}{c}\text { Stand } \\
\text { Dev }\end{array}$ & $\begin{array}{c}\mu \mathrm{g} \mathrm{g}^{-1} \\
\mathrm{dm}\end{array}$ & $\begin{array}{c}\text { Stand } \\
\text { Dev }\end{array}$ \\
\hline $\mathrm{N}$ & 1.810 & 0.402 & 1.464 & 0.329 & 0.739 & 0.140 & 0.618 & 0.127 & 1.273 & 0.240 & 1.041 & 0.200 \\
\hline $\mathrm{P}$ & 0.367 & 0.054 & 0.325 & 0.048 & 0.230 & 0.057 & 0.226 & 0.073 & 0.298 & 0.046 & 0.275 & 0.045 \\
\hline $\mathrm{K}$ & 2.192 & 0.373 & 2.034 & 0.388 & 0.542 & 0.166 & 0.629 & 0.173 & 1.367 & 0.231 & 1.331 & 0.221 \\
\hline $\mathrm{Ca}$ & 0.615 & 0.323 & 0.642 & 0.329 & 0.469 & 0.190 & 0.433 & 0.147 & 0.542 & 0.244 & 0.538 & 0.227 \\
\hline $\mathrm{Mg}$ & 0.230 & 0.063 & 0.236 & 0.072 & 0.170 & 0.047 & 0.145 & 0.030 & 0.199 & 0.049 & 0.190 & 0.044 \\
\hline $\mathrm{Fe}$ & 135.8 & 146.7 & 122.6 & 127.0 & 2331.4 & 1051.4 & 2091.5 & 1128.0 & 1233.6 & 514.0 & 1107.0 & 555.60 \\
\hline $\mathrm{Zn}$ & 35.81 & 6.215 & 34.99 & 4.725 & 23.06 & 9.13 & 17.69 & 80565 & 29.43 & 6.773 & 26.34 & 5.495 \\
\hline $\mathrm{Mn}$ & 188.4 & 43.15 & 211.0 & 50.73 & 277.85 & 123.6 & 263.1 & 113.34 & 233.14 & 63.02 & 237.0 & 60.62 \\
\hline $\mathrm{Cu}$ & 9.274 & 5.58 & 10.04 & 8.811 & 11.74 & 6.89 & 12.07 & 6.381 & 10.50 & 4.740 & 11.06 & 5.612 \\
\hline $\mathrm{Cr}$ & 1.391 & 0.722 & 1.378 & 0.823 & 18.94 & 9.55 & 20.24 & 13.88 & 10.17 & 4.638 & 10.81 & 6.944 \\
\hline $\mathrm{Cd}$ & 0.663 & 0.485 & 0.677 & 0.450 & 0.926 & 0.743 & 0.802 & 0.578 & 0.794 & 0.579 & 0.739 & 0.455 \\
\hline Co & 0.731 & 0.925 & 0.759 & 0.842 & 6.606 & 4.97 & 7.331 & 7.489 & 3.669 & 2.708 & 4.045 & 3.956 \\
\hline $\mathrm{Ni}$ & 1.594 & 0.680 & 1.604 & 0.590 & 8.682 & 3.94 & 8.143 & 4.522 & $5.137 *$ & 1.906 & 4.874- & 2.202 \\
\hline $\mathrm{Pb}$ & - & & - & & - & & 18.33 & & - & & - & \\
\hline
\end{tabular}

\subsection{Water and TMWW Analysis}

The TMWW was processed and analyzed by the procedure given by AOAC (1996) and APHA (1995). Natural fresh well water was analyzed for Electrical. Conductivity (EC), pH, SAR, $\mathrm{P}, \mathrm{K}, \mathrm{Ca}, \mathrm{Na}, \mathrm{Mg}, \mathrm{Fe}$, $\mathrm{Mn}, \mathrm{B}, \mathrm{Cl}, \mathrm{Zn}, \mathrm{Cu}, \mathrm{As}, \mathrm{Cr}, \mathrm{Cd}, \mathrm{Ni}<\mathrm{Pb}, \mathrm{Co}$ ) by the methods suggested by Richard (1954 and APHA, 1995). (Table 5)

According to Table 5, the inorganic synthesis of TMWW, with the exception of the $\mathrm{Na}$, whose concentration is very high compared to the WHO standards given above, all the other components were within the acceptable limits. Similarly, the characteristics of the irrigation water are within the allowed critical levels.

\subsection{Pollution Load Index (PLI)}

Among the aims of this research work was the study of the sludge and wastewater impact, on soil pollution. The assessment of soil pollution level with heavy metals, was possible by means of a simple mathematical relationship, i.e. of the pollution load index (PLI), which is basically the geometric mean of "concentration factors" (CF) of various metals which are involved in the pollution of the soil. The CF is equal to the ratio of the content of heavy metal in the soil to its corresponding reference value, i.e.: 
$\mathrm{CF}=\mathrm{M}_{\mathrm{s}} / \mathrm{Mr}_{\mathrm{r}}$

Where: $M_{s}$ is the concentration of metal in the soil $\left(\mathrm{mg} \mathrm{kg}^{-1}\right)$ and $\mathrm{Mr}_{\mathrm{r}}$ is the reference value of this metal (mg kg-1) (Ntzala, 2011).

Table 5. Chemical and physical characteristics of the two water sources studied in the experiment

\begin{tabular}{|c|c|c|c|c|c|}
\hline \multirow{3}{*}{ Chemical characteristics } & \multirow{3}{*}{$\begin{array}{c}\text { Maximum } \\
\text { allowable levels }\end{array}$} & \multicolumn{4}{|c|}{ Water source } \\
\hline & & \multicolumn{2}{|c|}{ TMWW (n=6) } & \multicolumn{2}{|c|}{ Natural water (control) } \\
\hline & & Mean & $\begin{array}{l}\text { Standard } \\
\text { deviation }\end{array}$ & Mean & $\begin{array}{l}\text { Standard } \\
\text { deviation }\end{array}$ \\
\hline Conductivity $\left(\mathrm{ms} \mathrm{cm}^{-1}\right)$ & 0.70 & 1.269 & 0.173 & 0.244 & 0.228 \\
\hline $\mathrm{pH}$ & $6.5^{*} 8.5^{\mathrm{b}}$ & 7.32 & 0.325 & 8.03 & 0.213 \\
\hline SAR & $<=3$ & 4.00 & 0.723 & 0.303 & 0.045 \\
\hline $\mathrm{NH}_{4}\left(\mathrm{mg} \mathrm{l}^{-1}\right)$ & - & 18.33 & 3.393 & 0.05 & 0.00 \\
\hline $\mathrm{P}\left(\mathrm{mg} \mathrm{l}^{-1}\right)$ & - & 0.90 & 1.098 & 0.015 & 0.0055 \\
\hline $\mathrm{K}\left(\mathrm{mg} \mathrm{l}^{-1}\right)$ & - & 11.67 & 4.082 & 0.95 & 0.0548 \\
\hline $\mathrm{Ca}\left(\mathrm{mg} \mathrm{l}^{-1}\right)$ & $0-400^{b}$ & 69.65 & 5.512 & 43.53 & 1.502 \\
\hline $\mathrm{Mg}\left(\mathrm{mg} \mathrm{l}^{-1}\right)$ & $0-60^{b}$ & 29.10 & 7.140 & 5.10 & 0.228 \\
\hline $\mathrm{Fe}\left(\mathrm{mg} \mathrm{l}^{-1}\right)$ & $5.0^{\mathrm{b}}$ & 0.09 & 0.102 & 0.02 & 0.0075 \\
\hline $\mathrm{Na}\left(\mathrm{mg} \mathrm{l}^{-1}\right)$ & $0-3.0$ & 162.0 & 28.114 & 7.66 & 1.211 \\
\hline $\mathrm{Mn}\left(\mathrm{mg} \mathrm{l}^{-1}\right)$ & $0.20^{a}$ & 0.082 & 0.0249 & 0.00068 & 0.0003 \\
\hline $\mathrm{B}\left(\mathrm{mg} \mathrm{l}^{-1}\right)$ & $<0.70$ & 0.33 & 0.082 & 0.27 & 0.082 \\
\hline $\mathrm{Cl}\left(\mathrm{mg} \mathrm{l}^{-1}\right)$ & $0-350$ & 274.17 & 118.84 & 12.00 & 4.648 \\
\hline $\mathrm{Zn}\left(\mathrm{mg} \mathrm{l}^{-1}\right)$ & $2.00^{a}$ & 0.003 & 0.00 & 0.003 & 0.00 \\
\hline $\mathrm{Cu}\left(\mathrm{mg} \mathrm{l}^{-1}\right)$ & $0.20^{a}$ & 0.0018 & 0.0012 & 0.0043 & 0.0028 \\
\hline As $\left(\mathrm{mg} \mathrm{l}^{-1}\right)$ & $0.10^{a}$ & 0.0031 & 0.0018 & 0.0012 & 0.0006 \\
\hline $\mathrm{Cr}\left(\mathrm{mg} \mathrm{l}^{-1}\right)$ & $0.10^{a}$ & 0.001 & 0.0024 & 0.0003 & 0.00015 \\
\hline $\mathrm{Cd}\left(\mathrm{mg} \mathrm{l}^{-1}\right)$ & $0.01^{a}$ & 0.00001 & 0.00 & 0.00001 & 0.00 \\
\hline $\mathrm{Ni}\left(\mathrm{mg} \mathrm{l}^{-1}\right)$ & $0.20^{a}$ & 0.012 & 0.0097 & 0.0023 & 0.0014 \\
\hline $\mathrm{Pb}\left(\mathrm{mg} \mathrm{l}^{-1}\right)$ & $5.00^{\mathrm{a}}$ & 0.0002 & 0.00 & 0.0003 & 0.00 \\
\hline $\mathrm{Co}^{\mathrm{b}}\left(\mathrm{mg} \mathrm{l}^{-1}\right)$ & $0.05^{a}$ & - & & & \\
\hline
\end{tabular}

The concentration factor (CF) is an indicator of soil pollution by a single heavy metal, while the PLI shows the overall pollution of soil by more than one heavy metals, and it is equal to the geometric mean, i.e. to the the $n$-ith root of the product of $n$ individual concentration factors (nCF), (Cabrera et al., 1999) i.e.:

$$
\mathrm{PLI}=\sqrt[n]{\mathrm{CF}_{1} \times \mathrm{CF}_{2} \times \mathrm{CF}_{3} \ldots \times \mathrm{CF}_{n}}
$$

In order to calculate the concentration factor it was necessary to know the reference values of the metals, of a given region. In the present case of the prefecture of Aitoloakarnania, where the experiment was conducted, the reference values of the metals were derived from soil samples taken from areas which are far away from pollution sources (industries, major highways, landfills, etc.) and as possibly evenly distributed in the area under consideration. Therefore, four compound soil samples were taken from 11 sites, scattered evenly all over the Aitoloakarnanian Prefecture i.e.: 1. Avlaki 2. Paleros, 3. Vonitsa 4. Lepenou, 5. Melegros, 6. Lesini, 7. Arakynthos, 8. Kallithea, 9. Mandrini, 10. Elatou and 11. Trikorfo. These sites are located away from sources of pollution. In total 44 soil samples were taken for the determination of $\mathrm{Cd}, \mathrm{Co}, \mathrm{Cr}, \mathrm{Zn}, \mathrm{Cu}, \mathrm{Mn}, \mathrm{Ni}$ and $\mathrm{Pb}$ content.; The following mean reference values were obtained shown in Table 6. 
Table 6. Heavy metals references values of the Aitoakarnanian Prefecture (Ntzala, 2011).

\begin{tabular}{c|c|c|c|c|c}
\hline Metal & $\mathrm{n}$ & Minimum & Maximum & Mean & $\begin{array}{c}\text { Standard } \\
\text { deviation }\end{array}$ \\
\hline $\mathrm{Fe}$ & 44 & 2.67 & 76.66 & 14.53 & 12.7676 \\
\hline $\mathrm{Cu}$ & 44 & 0.24 & 11.19 & 2.48 & 2.2851 \\
\hline $\mathrm{Mn}$ & 44 & 1.37 & 61.93 & 11.39 & 14.2377 \\
\hline $\mathrm{Zn}$ & 44 & 0.23 & 15.49 & 1.84 & 2.6023 \\
\hline $\mathrm{Cd}$ & 44 & 0.013 & 1.315 & 0.10 & 0.1890 \\
\hline $\mathrm{Co}$ & 44 & 0.023 & 0.459 & 0.11 & 0.1004 \\
\hline $\mathrm{Cr}$ & 44 & 0.00 & 0.039 & 0.012 & 0.0086 \\
\hline $\mathrm{Ni}$ & 44 & 0.066 & 2.594 & 0.90 & 0.6127 \\
\hline $\mathrm{Pb}$ & 44 & 0.049 & 2.165 & 0.57 & 0.3937 \\
\hline
\end{tabular}

\subsection{Statistical Analysis}

Experimental data was statistically processed by ANOVA, and regression analysis, using the statistical package of SPSS ver. 17.

\section{Results and Discussion}

The experimental results that have been obtained are given below and discussed accordingly as follows:

\subsection{Effect of sludge and TMWW on plant height}

It was shown that the plant height was significantly positively affected by the application of sludge (Table 7). A more detailed study of the effect of treatments on plant height, basically showed that the height was significantly increased under the effect of sludge at the fourth and fifth measurement. As the greenhouse was not heated, the actual effect of sludge on the height started much later than the transplanting date of lettuce, during which the temperature was low $\left(10-13^{\circ} \mathrm{C}\right)$. The actual effect of sludge started at the time the temperature of the greenhouse had been improved $\left(>15^{\circ} \mathrm{C}\right)$. The gradual increase of air temperature contributed to decomposition and mineralization of sludge organic matter, and consequently the release of nutrients $\mathrm{N}, \mathrm{P}$ and other micro-nutrients, which favored the plants growth. As shown in Table7, the mean plant height increased significantly at the fourth measument, and from a mean value of $15.86 \mathrm{~cm}$, increased to $26.75 \mathrm{~cm}$ at the fifth measurement.

Table 7. Descriptive statistics of the. effect of applied sludge treatments on the lettuce plant height in $\mathrm{cms}$

\begin{tabular}{cccccc}
\hline \multicolumn{7}{c}{ Descriptive Statistics } \\
\hline & $\mathrm{N}$ & Minimum & Maximum & Mean & Std. Deviation \\
\hline Firstheight & 28 & 8.00 & 9.60 & 8.6929 & .48605 \\
\hline Secondheight & 28 & 8.40 & 16.90 & 12.4750 & 2.10777 \\
\hline thirdheight & 28 & 10.00 & 17.90 & 13.5143 & 1.94626 \\
\hline fourthheight & 28 & 10.70 & 23.00 & 15.8679 & 2.89022 \\
\hline fifthheight & 28 & 13.40 & 62.50 & 26.7571 & 12.72671 \\
\hline Valid N (listwise) & 28 & & & & \\
\hline
\end{tabular}

Analysis of variance (ANOVA) indicated that the effect of sludge on plant height was statistically significant at the $4^{\text {th }}(F=8.501$ sign. 0.000$)$ and $5^{\text {th }}(F=3.201$ and sign. 0.025$)$ measurement.

\subsection{Effects of sludge on fresh and dry matter yields}

In Figures $1 \mathrm{~A}$ and $1 \mathrm{~B}$, fresh and dry matter yield was affected significantly under the effect of sludge. These results showed that the addition of sludge had positive effects on both dry and fresh matter yields. 
(A)

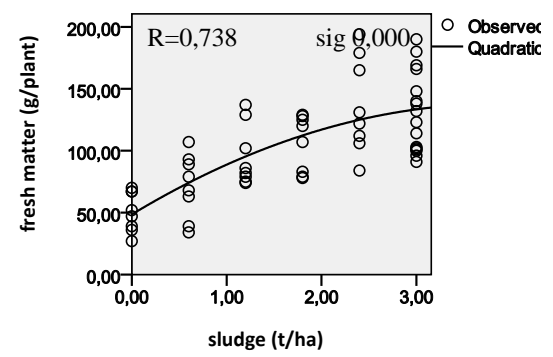

(B)

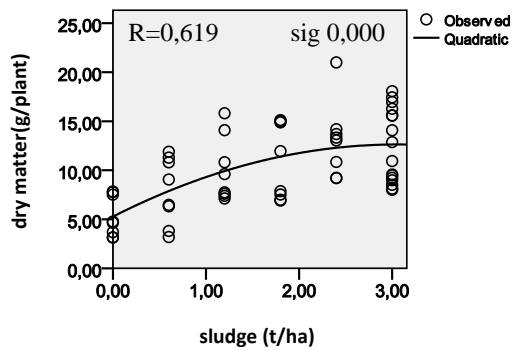

Figure 1. Effect of the applied sludge levels ( $t /$ ha) on the fresh $(A)$ and dry $(B)$ matter yield of lettuce heads (mean effect of both plant samplings $(n=56)$

Similarly, the effect of TMWW on both fresh and dry matter yields of lettuce head was statistically significant (Figure 2A and 2B).

(A)

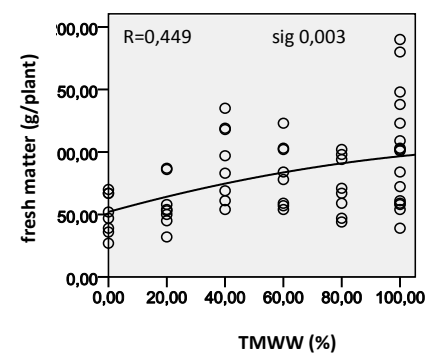

(B)

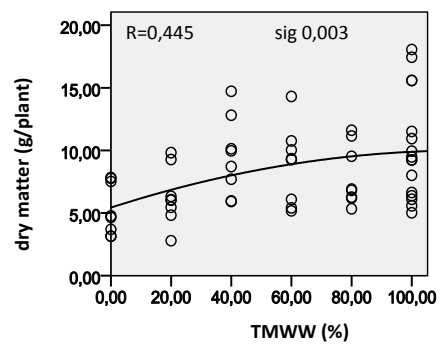

Figure 2. Effect of the applied TMWW levels on the fresh (A) and dry (B) matter yield of head (mean effect of both samplings) ( $n=56$ ).

\subsection{Effect of sludge and TMWW on physical and chemical characteristics of the soil}

In the context of the present study, the effects of sludge and TMWW on some physical and chemical characteristics of the soil, such as $\mathrm{pH}$, electrical conductivity (EC), organic matter, macro- and micronutrients, and heavy metals, were also studied.

Comparing the mean values of soil, $\mathrm{pH}$ under the effect of sludge and TMWW, respectively, it was found that the differences were statistically non-significant (Figure $3 \mathrm{~A}$ ) and under the TMWW (Figure $4 A$ ), suggesting that the effect of both sludge and TMWW on this parameter was similar, i.e. negative and quantitatively more or less equal.

However, the effect of TMWW on the soil EC was much stronger than that of sludge, increasing the EC from 0,40 to $2.10 \mathrm{mS} \mathrm{cm}^{-1}$ (Figure $4 \mathrm{~B}$ ) in comparison to that of sludge which increased $\mathrm{EC}$ from 0,45 to $1,1 \mathrm{mS} \mathrm{cm}^{-1}$ (figure 3B). These results are explained on the basis of the higher concentration of the

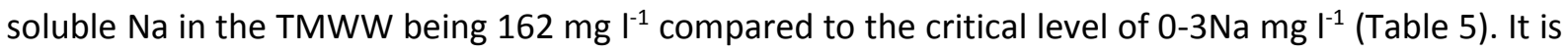
well known that $\mathrm{Na}$ ion is strong alkalizing factor, increasing the $\mathrm{pH}$ significantly (Richards, 1954). 

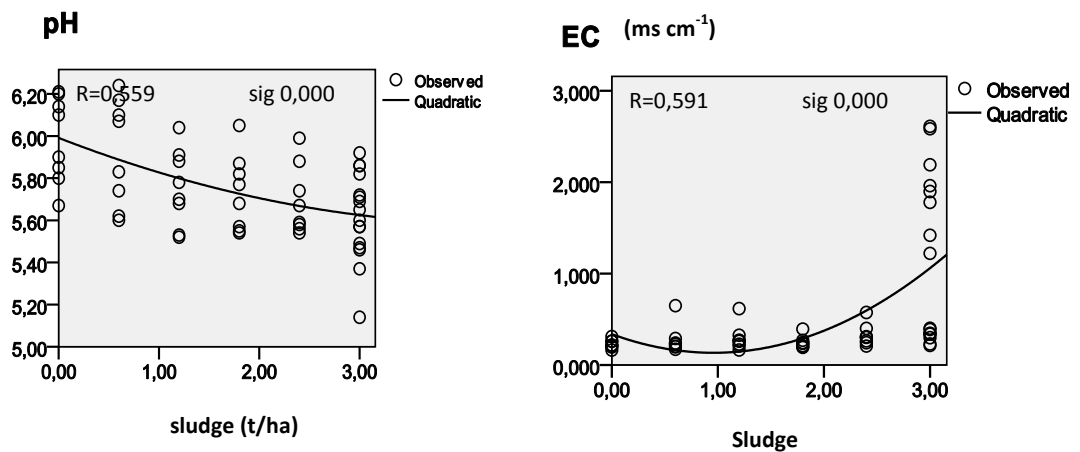

Figure 3: Effect of the applied sludge levels ( $\mathrm{t} / \mathrm{ha}$ ) on $\mathrm{pH}$ and electrical conductivity (EC) of soil, during both samplings $(n=48)$

(A)

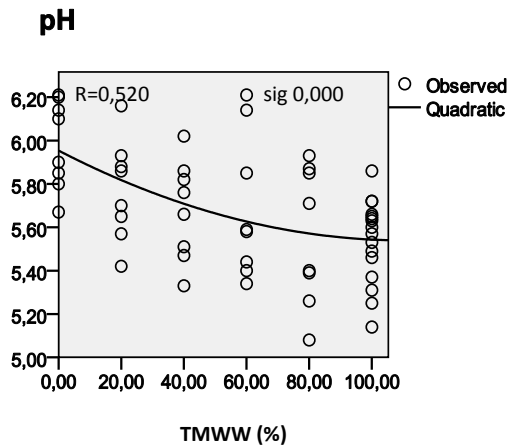

(B)

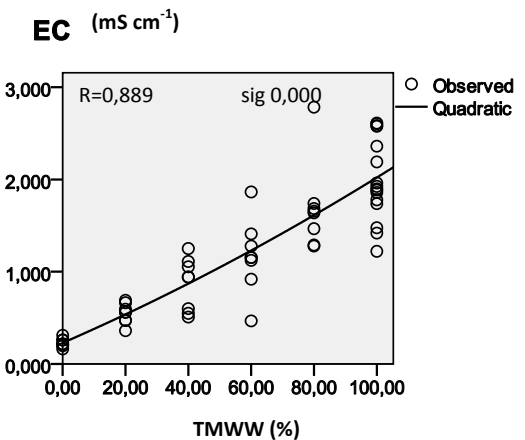

Figure 4. Effect of TMWW treatments on $\mathrm{pH}$ and electrical conductivity $(\mathrm{EC})$ of soil, during both samplings $n=58$

3.4 Effect of sludge and TMWW on the nutrient and heavy metal content of heads, roots and whole plant dry matter

Application of sludge $(S)$ increased linearly and statististically significantly the lettuce whole plant $N$, the head $\mathrm{N}$ and the root $\mathrm{N}$ content, as shown by the following regression analysis:

\begin{tabular}{cccc}
\hline Plant organ & Regression equation & $R$ & significance \\
\hline Whole plant & $\mathrm{N} \%(\mathrm{dm})=0.013(\mathrm{~S})+1.045$ & 0.610 & 0.001 \\
\hline Heads & $\mathrm{N} \%(\mathrm{dm})=0.022(\mathrm{~S})+1.438$ & 0.590 & 0.001 \\
\hline Roots & $\mathrm{N} \%(\mathrm{dm})=0,005(\mathrm{~S})+0.652$ & 0.399 & 0.035 \\
\hline
\end{tabular}

Contrary to sludge, the application of TMWW increased only the root $\mathrm{N}$ content of lettuce, the regression equation being quadratic, and statistically significant, i.e. : $N \%(d m)=5.49 E .005(T M W W)^{2}-$ 0.006 (TMWW) + 0.650 ( $\mathrm{R} 0.512$, significance 0.023 ).

Excluding the $\mathrm{N}$, the comparative study of the effect of sludge, and TMWW, on the macro, micronutrient and heavy metal head, root and whole plant content, respectively disclosed that neither of the above treatments affected significantly the mineral content of these lettuce plant parts As indicated by the analysis of t-test shown in Table 8 ,, the correlation coefficient between the compared 
pairs is highly significant $(0,999)$ and the t value non significant, suggesting that the difference between the treatments studied were statistically non significant and that both of these treatments had the same effect on the mineral composition of lettuce plant parts.

Table 8. Pair t-test analysis between the sludge and TMWW effect on the mineral content of lettuce head, root and whole plant dry matter

\begin{tabular}{|c|c|c|c|c|c|c|c|c|}
\hline \multirow{3}{*}{ Pairs compared } & \multicolumn{4}{|c|}{ Paired differences } & \multirow{3}{*}{$\begin{array}{c}\text { Paired } \\
95 \% \\
\text { Confid. } \\
\text { Upper }\end{array}$} & \multirow{3}{*}{$\mathbf{t}$} & \multirow{3}{*}{ df } & \multirow{3}{*}{$\begin{array}{l}\text { Signif } \\
\text { (two- } \\
\text { tailed) }\end{array}$} \\
\hline & \multirow[t]{2}{*}{ Mean } & \multirow{2}{*}{$\begin{array}{c}\text { Stand. } \\
\text { Deviation }\end{array}$} & \multirow{2}{*}{$\begin{array}{c}\text { Standard } \\
\text { error }\end{array}$} & $\begin{array}{c}95 \% \\
\text { confidence }\end{array}$ & & & & \\
\hline & & & & & & & & \\
\hline $\begin{array}{c}\text { Pair1 } \\
\text { (h.SLUDGE- } \\
\text { h.TMWW) }\end{array}$ & 0.681 & 7.521 & 2.086 & -3.863 & 5.226 & 0.327 & 12 & $0.749 \mathrm{~ns}$ \\
\hline $\begin{array}{c}\text { Pair2 } \\
\text { (r.SLUDGE- } \\
\text { r.TMWW) }\end{array}$ & 18.518 & 63.863 & 17.068 & -18.355 & 55.392 & 1.085 & 13 & $0.298 \mathrm{~ns}$ \\
\hline $\begin{array}{c}\text { Pair3 } \\
\text { (wp.SLUDGE- } \\
\text { wp.TMWW) }\end{array}$ & 9.832 & 35.134 & 9.746 & -11.402 & 31.065 & 1.009 & 12 & $0.333 n s$ \\
\hline
\end{tabular}

The letters $r, h$, and wp in front of SLUDGE and TMWW stand for root, headsn and whole plants, respectively

\subsection{The impact of sludge and TMWW on soil pollution}

Among the main objectives of this work was to study and evaluate the level of soil pollution that may be caused by applying high levels of sludge and the long term reuse of TMWW and sludge. Despite of their favorable properties (high macro- and micro nutrients content, organic matter, and water), these two inputs also have a major drawback. They contain large amounts of heavy metals, (Stabnikova et al.,2005; Akdeniz et al, 2006) toxic compounds and various pharmaceutical substances and xenobiotics, which can easily enter into the food chain, eventually causing undesirable effects on the consumers' health (Fata-Kassinos et al., 2010).

Long-term application of sludge or TMWW in agricultural soils at high rates can cause pollution due to the accumulation of heavy metals (Liu et al., 2005; Zhang et al., 2012. In this work, the experimental soil used, was a non polluted one. Therefore, sludge was applied at low and very high levels varying from 0 to $30 \mathrm{t} / \mathrm{ha}$, in order to create a variable degree of soil contamination level. The objective was the evaluation of soil pollution level that would be caused by the addition of sludge, based on Pollution Load Index (PLI) (Tomlinson et al., 1980).

The PLI was calculated for the various treatment levels of sludge and TMWW and the results obtained are given in Table 8.

The study of the data of this Table reveals the following: The values of the PLI corresponding to the treatment levels of the sludge and TMWW, were low at the first soil sampling, while they increased at the second sampling. These results are explained on the basis of the increase of temperature after the $1^{\text {st }}$ soil sampling. Before this sampling, the air temperature was $<15{ }^{\circ} \mathrm{C}$. As a result soil chemical and biological processes (decomposition and mineralization of organic, organic metal complex formation) were less active, and the heavy metals were not released into the soil, consequently the PLI did not increase substantially. Therefore, plant growth and soil contamination were not differentiated.

The minimum and maximum PLI values attained at the $1^{\text {st }}$ and $2^{\text {nd }}$ soil sampling under both the treatments studied, ranged between $0,75-1,00$ \& 1,14-1,26 under sludge, and 0.61 to $1.09 \& 1,33-$ 1,55, under TMWW, respectively (Table 8). Previous work of Kalavrouziotis and Koukoulakis (2011) showed that the optimum PLI calculated under the effect of TMWW reuse varied from1.99 to 2.50 and the cabbage dry matter losses related to these PLI values ranged from 1-11\%, which were considered normal. 
Table 9. Calculated Pollution Load Index under sludge and TMWW, respectively, at the $1^{\text {st }}$ and $2^{\text {nd }}$ soil sampling, on the basis of the soil analytical data

\begin{tabular}{|c|c|c|c|c|c|}
\hline \multicolumn{3}{|c|}{ SLUDGE } & \multicolumn{3}{|c|}{ TMWW } \\
\hline \multirow{2}{*}{$\begin{array}{c}\text { Applied levels } \\
\text { t/ha }\end{array}$} & \multicolumn{2}{|c|}{ PLI } & \multirow{2}{*}{$\begin{array}{c}\text { Applied } \\
\text { treatments } \\
\%\end{array}$} & \multicolumn{2}{|c|}{ PLI } \\
\hline & $\begin{array}{c}1^{\text {st }} \text { soil } \\
\text { sampling }\end{array}$ & $\begin{array}{c}2^{\text {nd }} \text { soil } \\
\text { sampling }\end{array}$ & & $\begin{array}{c}1^{\text {st }} \text { soil } \\
\text { sampling }\end{array}$ & $\begin{array}{c}2^{\text {nd }} \text { soil } \\
\text { sampling }\end{array}$ \\
\hline Control(0) & 0.75 & 1.14 & Control(0) & 0.61 & 1.42 \\
\hline 6 & 0.91 & 1.20 & 20 & 0.77 & 1.43 \\
\hline 12 & 0.81 & 1.26 & 40 & 0.98 & 1.38 \\
\hline 18 & 0.87 & 1.20 & 60 & 0.93 & 1.52 \\
\hline 24 & 1.00 & 1.22 & 80 & 0.98 & 1.33 \\
\hline 30 & 0.90 & 1.23 & 100 & 1.04 & 1.37 \\
\hline $30+100 \%$ TMWW & 0.82 & 1.18 & $100+30 t$ sludge & 1.09 & 1.42 \\
\hline
\end{tabular}

\subsubsection{Relation between PLI and lettuce plant yield}

In spite of the increase of the PLI values, it was found that this index was statistically significantly and curvilinearly related to lettuce yields, under the effect of sludge, and TMWW (Figure 5). This relationship is described by the following regression by equation for the sludge and the TMWW:

1- Under sludge: Dry matter $=-9.439(\mathrm{PLI})^{2}+37.438(\mathrm{PLI})-11.883(\mathrm{R} 0.686 .0$ sign 0.000$)$ :

2- Under TMWW: Dry matter $=-1,183(P L I)^{2}+13.322(P L I)+1.242,\left(R^{2}=0.418\right.$, sign 0.000$)$

Although it was expected that a decrease of lettuce dry matter yield would have occurred with the increase of PLI, this did not occur, because soil contamination by sludge and TMWW born metals, was very small (Table 8). Figure 5 shows that the value of PLI equal to 1.50 corresponds to the maximum lettuce plant dry matter yield under both the effect of sludge( $15 \mathrm{~g} / \mathrm{plant})$ and TMWW( $24 \mathrm{~g} /$ plant $)$, respectively. These results suggest that the critical value of PLI $\leq 1$, set forth by Cambrera (1999) must be increased according to the capacity of the plant to resist the heavy metals.

(A)

TMWW

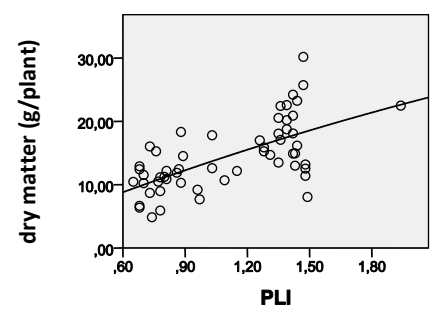

(B)

SLUDGE

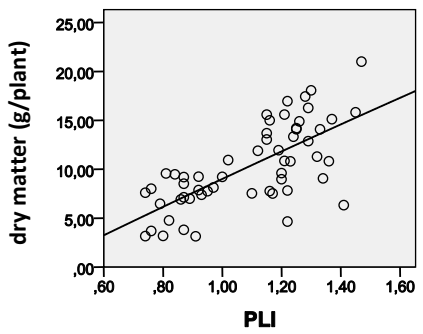

Figure 5. Relationship between PLI and lettuce plant dry matter yield (in grams per plant) under the effect of sludge and TMWW

\subsubsection{Relation between PLI and lettuce plant dry matter mineral composition}

Since PLI is an indicator of the degree of soil contamination, it is expected to be directly related to the content of plant nutrients and heavy metals. Therefore, the relationship between PLI and mineral composition of lettuce plants, under the effect of sludge and TMWW, was investigated.

The data of Table 10 shows that the interaction of PLI with most micro-, macro-nutrients of lettuce head and roots, was mainly synergistic and statistically significant 0.000 ), under the effect of sludge 
and TMWW, respectively. This means that as the PLI increases, the nutrient and metal plant dry matter content also increases Only between the $\mathrm{PLI}$ and $\mathrm{Cd}, \mathrm{Co}$ and $\mathrm{Ni}$, the relation is negative-antagonistic in lettuce heads, and roots, both under sludge, and TMWW, respectively (Table 10), suggesting that the increase of PLI reduces the dry matter content of the above three heavy metals in the plant.

These results are reflected in Figure 5 where the positive and statistically significant effect of PLI on dry matter yield is clearly shown. Since the PLI is positively and statistically significantly related to the macro and micronutrients, this relationship resulted in the increases of their concentration in the plants, and hence the plant growth was favourably affected.

Table 10. Relationship between PLI and lettuce root and head mineral composition, under the effect of sludge and TMWW

\begin{tabular}{|c|c|c|c|c|c|c|c|c|}
\hline \multirow{3}{*}{$\begin{array}{c}\text { Relationship } \\
\text { between PLI and } \\
\text { metals }\end{array}$} & \multicolumn{4}{|c|}{ Under the effect of TMWW } & \multicolumn{4}{|c|}{ Under the effect of sludge } \\
\hline & \multicolumn{2}{|c|}{ Roots } & \multicolumn{2}{|c|}{ Heads } & \multicolumn{2}{|c|}{ Roots } & \multicolumn{2}{|c|}{ Heads } \\
\hline & sign & type & sign & type & sign & type & sign & type \\
\hline PLI vs Ca & 0.000 & $\mathrm{~S}$ & 0.000 & $S$ & 0.000 & $\mathrm{~S}$ & 0.000 & $\mathrm{~S}$ \\
\hline PLI vs Mg & 0.000 & $\mathrm{~S}$ & 0.000 & $S$ & 0.000 & $\mathrm{~S}$ & 0.020 & $S$ \\
\hline PLI vs Fe & 0.001 & $\mathrm{~S}$ & 0.000 & $\mathrm{~A}$ & 0.000 & $\mathrm{~A}$ & 0.002 & $S$ \\
\hline PLI vs Zn & ns & - & 0.000 & $S$ & 0.045 & $\mathrm{~S}$ & ns & - \\
\hline PLI vs Mn & 0.032 & $\mathrm{~S}$ & 0.002 & $S$ & 0.007 & $S$ & ns & - \\
\hline PLI vs Cu & 0.030 & $\mathrm{~S}$ & ns & - & ns & - & 0.019 & $S$ \\
\hline $\mathrm{PLI}$ vs $\mathrm{Cr}$ & ns & - & 0.000 & $S$ & $\mathrm{~ns}$ & - & ns & - \\
\hline PLI vs Cd & 0.000 & A & 0.000 & A & 0.000 & A & 0.000 & A \\
\hline PLI vs Co & 0.000 & A & 0.000 & $A$ & 0.004 & $A$ & 0.000 & $A$ \\
\hline PLI vs Ni & 0.001 & $S$ & 0.000 & A & 0.000 & A & 0.000 & $S$ \\
\hline $\mathrm{PLI}$ vs $\mathrm{Pb}$ & - & - & - & - & - & - & 0.000 & $S$ \\
\hline PLI vs $P$ & 0.009 & $S$ & $\mathrm{~ns}$ & - & 0.000 & $S$ & ns & - \\
\hline PLI vs K & 0.007 & $S$ & ns & - & 0.001 & $S$ & 0.007 & $S$ \\
\hline PLI vs Ca & 0.000 & $S$ & 0.000 & $S$ & 0.000 & $S$ & 0.000 & $S$ \\
\hline PLI vs Mg & 0.000 & $S$ & 0.020 & $S$ & 0.000 & $S$ & 0.023 & $S$ \\
\hline
\end{tabular}

$A=$ interaction competitive, $S=$ synergistic, $0.000=$ statistical significant $1 \%$

\section{Conclusions}

The conclusions drawn from the aforementioned discussion are summarized as follows:

The increase of plant height was statistically significant under the effect of sludge, while it was nonsignificant under the TMWW.

Both sludge and TMWW affected positively and statistically significantly soil $\mathrm{pH}$ and negatively soil electrical conductivity (EC), the effect of TMWW being much higher

Also, the addition of sludge increased the head,root and whole plant dry matter $\mathrm{N}$ content, while irrigation with TMWW increased significantly the total root $\mathrm{N}$ and $\mathrm{P}$ concentration.

The increase of PLI under the treatments studied, was considered low as shown by the positive relation of the PLI with plant dry matter production.

The relation between PLI and the plant macro and micronutrients of the head and root dry matter content was synergistic, and statistically significant, while between $\mathrm{Cd}, \mathrm{Co}$ and $\mathrm{Ni}$, plant content, was antagonistic, relationships, which affected favorably the plant growth. It was concluded that the applied sludge and TMWW treatments polluted the soil only slightly.

\section{References}

Adriano D.C., 2001 Trace elements in terrestrial environment Biochemistry, Bioavailabiolity and Risks of Metals $2^{\text {nd }}$ Edition Springer 2001 New York 
Akdeniz H., Yilmaz I., Bozkurt M.A. and Keskin B. (2006), The effects of sewage sludge and nitrogen appliocation on grain sorghum Grown (Sorghum vulgare, L.) in Van-Turkey, Polish Journal of Environmental Studies, 15, 19-26.

Antonius G.F., Snyder J.C. and Denis S.O. (2010), Heavy metals in summer squash fruits, grown in soil amended with municipal sewage sludge, Environmental Science and Health part B, 45, 167-173.

AOAC, 1996. Official Methods of Analysis of AOAC International, $16^{\text {th }}$ Edition Publication International Suite AOAC, 481 Frederic Ave. Gaithersburg, Maryland 2027-2417, USA.

APHA, 1995. Standard Methods for Examination of water and wastewater. Method 3110, 19 ${ }^{\text {th }}$ Edition, American Public Health Association, Washington, D.C. USA.

Cabrera F., Clemente L., Diaz Barrientos E., Lopez R. and Murillo J.M. (1999), Heavy metal pollution of soils affected by the Guadiamar toxic flood, The Science of the Total Environment, 242, 117-129.

EC (2002), Communication of 16 April, 2002 from the Commission to the Council, the European Parliament, the Economic and social Committee, and the Committee of Regions towards a thematic strategy for soil protection, European Commission Brussels: Belgium p39.

FAO 2003.Users manual for Irrigation with treated wastewater, FAO regional Office for Near East, Cairo 2003

Fata-Kassinos D., Kalavrouziotis I.K., Koukoulakis P.H. and Vasquez M.I. (2011), The risks associated with wastewater reuse and xenobiotics in the agroecological environment, The Science of the Total Environment, 409, 3555-3563.

Ferguson C. C. (1999), Assessing risks from contaminated sites: policy and practice in 16 European countries, Land Contamination and Reclamation, 7(2), 33-54.

Friberg L (1948), Proteinuria and kidney injury among workmen exposed to cadmium and nickel dust, J. Ind. Toxicol., 30, 32-36.

Govil P.K., Reddy G.L.N. and Krishna A.K. (2001), Contamination of soil due to heavy metals in the Patancheru industrial development area, Andhra Pradesh India, Environmental Geology, 41, 461-469.

Jarup L. (2003), Hazards of heavy metal contamination, British Medical Bulletin, 68, 167-182.

Kalavrouziotis I.K., Robolas P. Koukoulakis P.H. and Papadopoulos A.H. (2008), Effects of municipal reclaimed wastewater on the macro- and microelements status of soil and Brassica oleracea var Italica, and Brassica Oleracea var Gemmifera, Agricultural Water Management, 95, 419-426.

Kalavrouziotis I.K. and Koukoulakis P.H. (2011), Soil pollution under the effect of treated municipal wastewater, Environ. Monit. Assess, DOI 10.1007/s 10661-011-2420-0

Kalavrouziotis I.K., Rezapour S. and Koukoulakis P.H. (2013), Wastewater status in Greece and Iran, Fresenius Environmental Bulletin, 22(1), 11-20.

Lanyon L.E. and Heald W.R. (1982), Magnesium, Calcium, Strontium and Barium. In: Page A.L., Miller R.H. and Keeney D.R. (eds) Methods of soil analysis, Part 2, Agronomy 9, American Society of Agronomy Madison, Wisconsin, pp 247-262.

Lindsay W.L. and Norvell W.A. (1978), Development of DTPA test for zinc, iron manganese and copper, Soil Sci. Soc. Amer. J., 42, 421-428.

Liu W-h, Zhao J-z, Ouyang Z-y, Söderlund L. and Liu G-h. (2005), Impacts of sewage irrigation on heavy metal distribution and contamination in Beijing, China, Environmental International, 31, 805-812.

Metcalf and Eddy Inc. 1991.Wastewater engineering, treatment, disposal and reuse, New York Mcgraw and Hill NRC (1996), Use of reclaimed water and sludge in Food Crop Production. National Research Council, USA p34

Ntzala G. (2011), Investigation on the pollution degree of soil with treated municipal wastewater reuse and sludge and their impact on soils and on Lettuce (Lactuca sativa, L. var Longifolia. MS Thesis, University of loannina, (In Greek)

Olsen S.R., Cole J.V., Watanabe F.S. and Dean L.A. (1954), Estimation of available phosphorus in soils by extraction with sodium bicarbonate, Circular 939 USDA, Washington USA.

Pereira B.F.F., He Z.L., Stoffela P.J. and Melfi A.J. (2011), Reclaimed wastewater effects on citrus nutrition, Agricultural Water Management, 98, 1828-1833. 
Purves D. (1977), The contamination of soil and food crops by toxic elements normally found in municipal wastewaters and the consequences for human health, in Wastewater Renovation and Reuse, D' Itri, F. M., Ed., Marcel Dekker, New York, 257.

Richards L.A. (1954), Diagnosis and improvement of saline and alkaline soils, Agricultural Handbook No 60 USDA, Washington, D.C., USA. P 94.

Stabnikova O., Gog W.K., Ding H.B., Tay J.H. and Wang J.Y. (2005), The use of sludge and horticultural waste to develop artificial soil for plant cultivation in Singapore, Biosource Technology, 96, 1073-1080.

Soltanpour P.N., Johnson C.W., Workman S.M., Jones J.B. Jr. and Miller R.O. (1998), Advances in ICP emission and ICP mass spectroscopy, Adv. Agron., 64, 28-113.

Tomlison L., Wilson G., Haris R. and Jeffery D.W. (1980), Problems in the assessments of heavy metal levels in estuaries and formation of a pollution index, Helgoländer Meeresunters, 33, 566-575.

Tsuchiya K. (1967), Proteinuria of workers exposed to cadmium fumes. The relationship to concentration in the working environment, Arch. Environ. Health., 14, 875-880.

Ure A.M. (1995), Methods of analysis for heavy metals in soils. In: Alloway, B.J. Heavy Metals in Soil, $2^{\text {nd }}$ Edition, Blackie Academic and Professional An Imprint of Chapman and Hall, London, p. 58.

WHO (1992) Cadmium, Environmental Health Criteria vol. 134, Geneva World Health Organization, ppl-280.

Zhang Z., Jin F., Wang C., Luo G., Lin H., Xiang K., Liu L., Zhao M., Zhang Y., Ding H., Zhou S., Shen Y. and Pan G. (2012), Difference between $\mathrm{Pb}$ and $\mathrm{Cd}$ accumulation in 19 Elit Maize inbred lines, and application prospects, Journal of Biomedicine and Biotechnology, Article ID 271485 pages 6, Doi: 10.1155/2012/271485. 